\title{
RAPID KARST DEVELOPMENT IN AN ENGLISH QUARTZITIC SANDSTONE
}

\section{HITRI RAZVOJ KRASA V ANGLEŠKIH KVARCITNIH PEŠČENJAKIH}

CHARLES A. SELF ${ }^{1} \&$ GRAHAM J. MULLAN ${ }^{2}$

${ }^{1}$ Charles A. Self, 4 Tyne Street, Bristol, BS2 9UA, England, e-mail: self @ globalnet .co.uk

${ }^{2}$ Graham J. Mullan, 38 Delvin Road, Bristol, BS10 5EJ, England., e-mail: graham.mullan@wotcc.org.uk 


\section{Abstract}

UDC: $551.435 .8(410.1) " 627 "$

\section{Charles A. Self \& Graham J. Mullan: Rapid Karst development in an English Quartzitic Sandstone}

Many karst features, including caves, have been found in the outcrop of the Fell Sandstone in Northumberland, England. These features are Holocene in age, since the area was glaciated during the Devensian cold stage. It is suggested that tectonic inception and selective arenisation of rock faces that remain damp are responsible for these karst features. The limitations of textbook definitions of the term karst are discussed.

Key words: sandstone karst, rapid arenisation, piping, tectonic inception.

Izvleček

UDK: 551.435.8(410.1)"627"

\section{Charles A. Self \& Graham J. Mullan: Hitri razvoj krasa v angleških kvarcitnih peščenjakih}

Na izdankih Fellskih peščenjakov v pokrajini Northumberland v Angliji, se pojavlja več kraških oblik, med njimi tudi jame. Kraške oblike so nastale v holocenu, saj je bilo območje v Devenzijski hladni dobi pokrito z ledenikom. Predvidevamo, da je nastanek teh oblik povezan z incepcijo tektonske dejavnosti in hitro arenizacijo (selektivnim preperevanjem vlažnih) kamnitih površin. V članku razpravljamo tudi o omejenosti splošno sprejetih definicij termina kras.

Klučne besede: kras v peščenjakih, hitro preperevanje, cevljenje, tektonska incepcija. 


\section{THE FELL SANDSTONE OF NORTHUMBERLAND}

The Fell Sandstone is a Viséan (Lower Carboniferous) formation which outcrops in an arc along the England/ Scotland border south-west from Berwick upon Tweed (Figure 1), with the greater part in the county of Northumberland in north-east England. Here the formation is between $240 \mathrm{~m}$ and $300 \mathrm{~m}$ thick and has a particularly uniform lithology of well-sorted, medium grained quartz arenites. Cross-bedding is commonly seen. The sandstone units are often separated by thin beds of argillaceous silt, and there are occasional thin conglomerate bands containing pebbles up to $25 \mathrm{~mm}$ in diameter. The sandstones are generally highly indurated with a cement of quartz overgrowths and

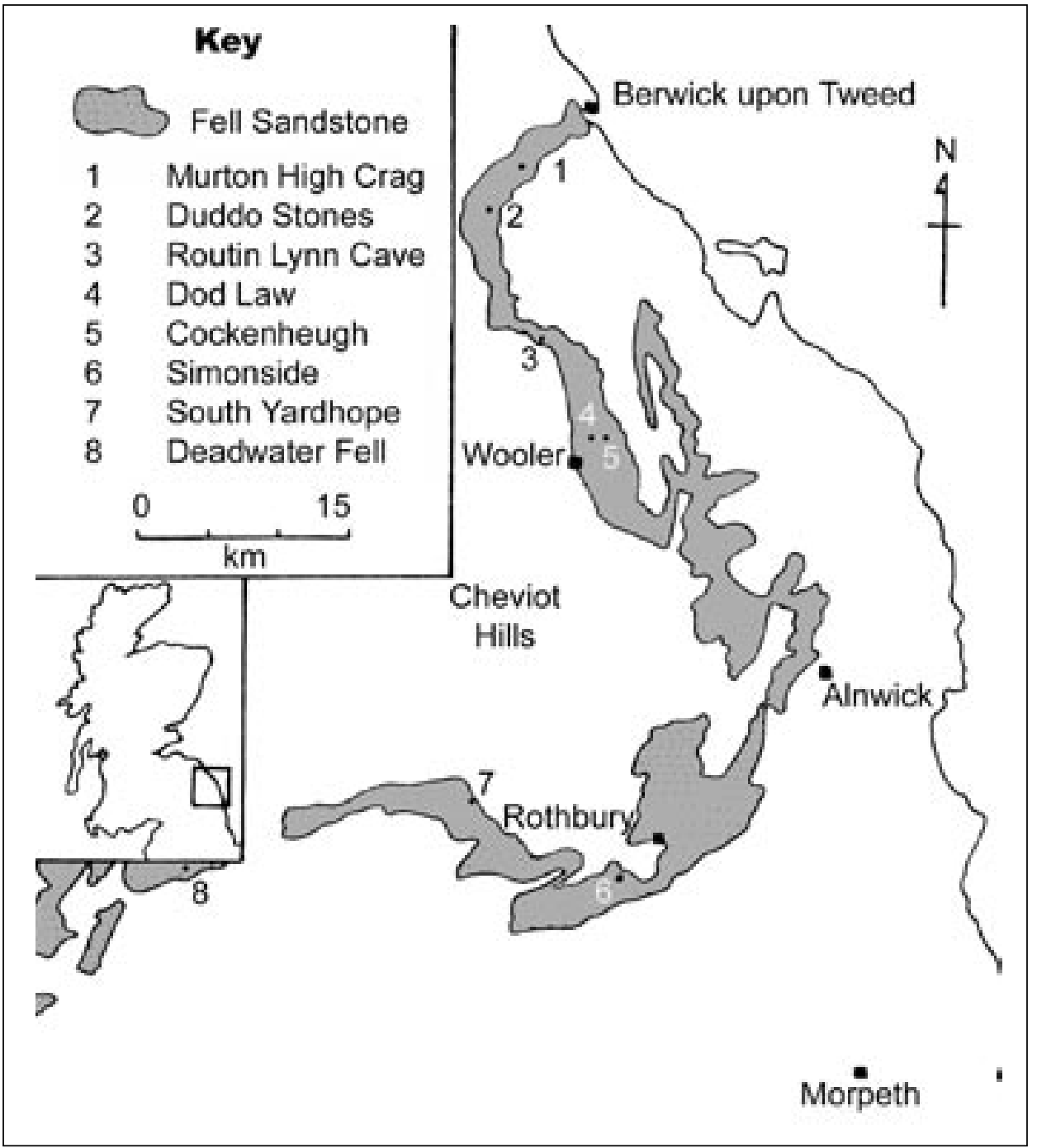

Figure 1: Location and area map. 
pyrite (Younger and Stunell, 1995). It should be stressed that the Fell Sandstone has no significant calcareous content. The outcrop forms barren, heathery moorland hills with frequent exposures of bare rock in craggy escarpments around the higher (granite) Cheviot Hills. Because of a gentle dip towards the south and east, the outcrop is generally only two or three kms wide (Robson, 1956; Turner et al., 1993).

This formation originally came to the authors' notice because of its caves, but all the other distinctive features of a karst suite have been found here. We have not made a complete investigation of the entire outcrop, but the majority of the rock exposures between Berwick on Tweed and Kielder have been visited. These occur at frequent intervals along the length of the outcrop and none have been found which do not demonstrate at least one karst feature. On many exposures, karst features are numerous.

Small elliptical tubes and proto-caves are found throughout the outcrop, but only about ten can be described as caves (i.e. large enough to be explored by humans). All the caves are quite short, the longest being Routin Lynn Cave (NGR NT 982368) at not quite 10 metres (Figure 2). This cave has poorly developed scalloping on its ceiling. The caves are all former resurgences and rapidly reduce in size inside. This morphology is typical of piping, whereby most of the material is removed in suspension and the cave develops from the resurgence by headward sapping. All the caves and most of the proto-caves are now dry, but an active stream sink may be found at South Yardhope Crag (NGR NT 925005). Here a small stream drops down a $1.5 \mathrm{~m}$ waterfall in an enlarged joint (Figure 3), to resurge nearby at the bottom of a cliff. At Deadwater Fell (NGR NY 624980) there is a system of at least 15 dolines, where a number of small streams sink to feed a seepage area at the base of a cliff.

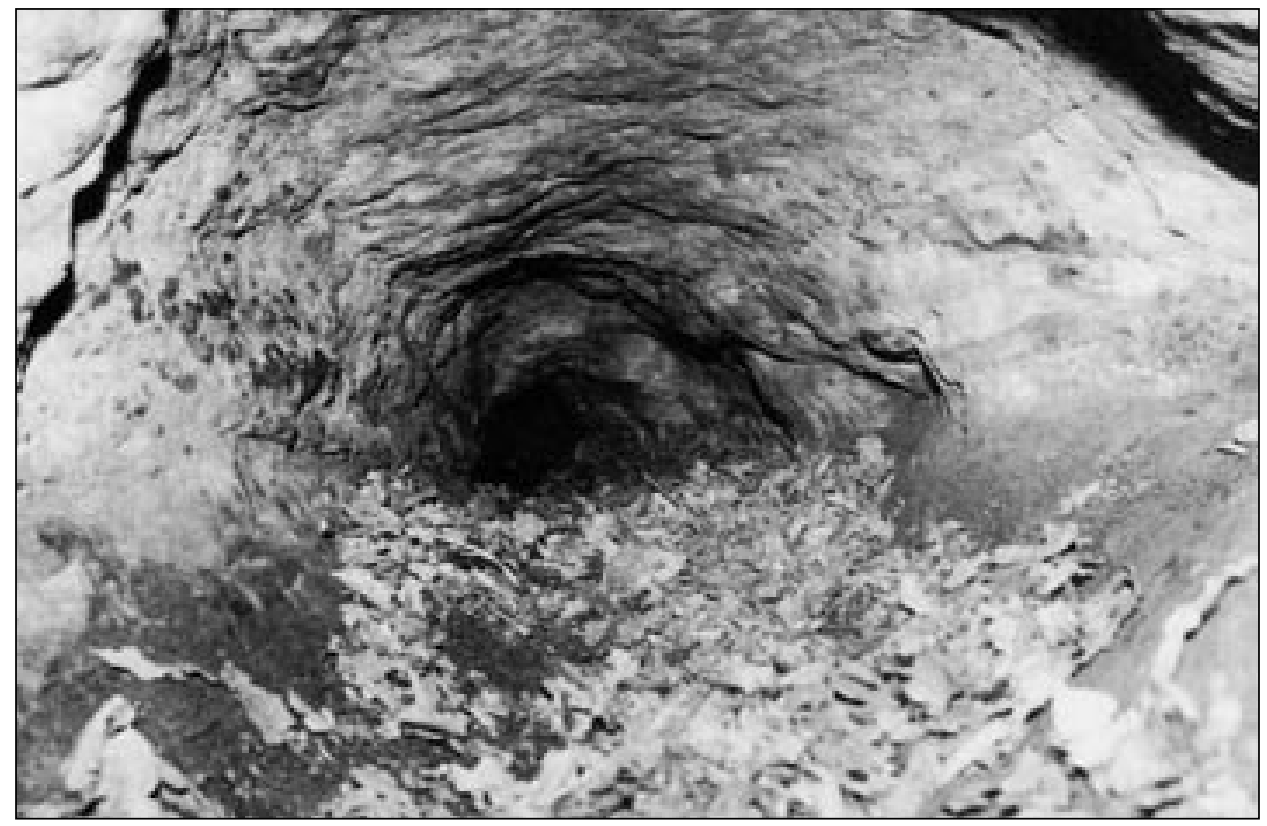

Figure 2: Internal view of Routin Lynn Cave. 
Short dry caves are also present here. A cave remnant, and another on Simonside (NGR NZ 026988), could be from an older cycle of erosion; they are both rock windows through a cliff promontary and therefore oriented perpendicular to the present natural direction of underground drainage.

Fluted rock outcrops and karren can be found on many crags, with particularly good examples on Dod Law (NGR NU 004310), Murton High Crags (NGR NT 962495) and Cockenheugh (NGR NU 062347). Pan forms (kamenitza) are present at Little Church Rock, Simonside (NGR NZ 026993) and elsewhere. Spectacular decantation runnels can be found on the Duddo Stones (NGR NT 931437), a late Neolithic standing stone circle (Figure 4), as well as on many natural cliff edges.

\section{PROCESS AND SPEED OF FORMATION OF KARST LANDFORMS}

Relatively little scientific research has been conducted on karst development in arenaceous rocks, though karst-like landforms have been identified in many countries and in many different lithologies. The most extensive caves have developed in quartzite, a metamorphosed sandstone composed of interlocking quartz grains. Weathering involves dissolution of quartz along crystal boundaries, a process known as arenisation since it weakens the rock firstly to a neosandstone and eventually

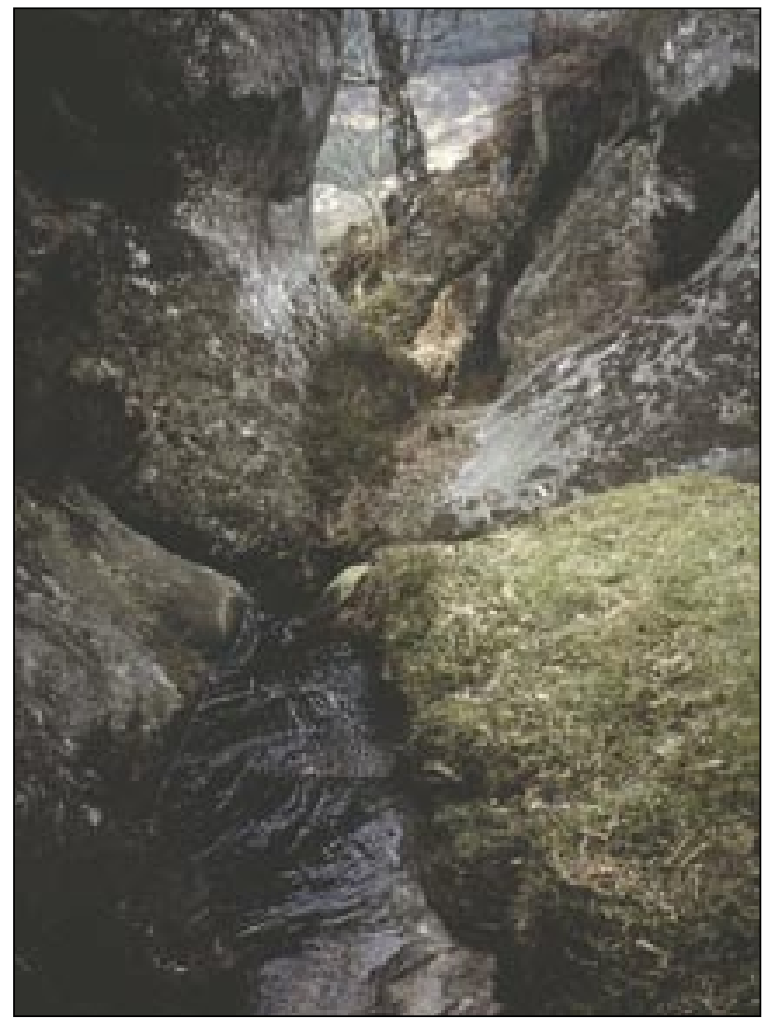

Figure 3: Stream sink and dry valley continuation, South Yardhope Crag. to loose sand. Cave development is by piping, the mechanical removal of material by flowing water. The preferential distribution of quartzite caves in countries with a warm and humid climate is because a thick vegetation cover protects the weathered rock from surficial erosion. Research in Venezuela, northern Australia and southern Africa suggests that the arenisation process takes several millions of years, whereas piping and cave development may only need a few thousand years (Martini, 2004). Most caves still have active streams and so are still developing.

The Fell Sandstone outcrop in Northumberland was glacially eroded in the Devensian cold stage, so the karren and shallow epikarst described above have developed under temperate, humid climate conditions within the last 13,000 years. A few proto-caves still have flowing water, but the majority (and all the caves) are dry. They appear to have formed by a similar mechanism to caves in 
other arenaceous rocks, yet the entire process of arenisation and piping can only have taken a few thousand years.

There are lithological reasons why the Fell Sandstone may be prone to rapid arenisation. Firstly, it is an important aquifer and has a significant primary porosity. This allows undersaturated groundwater to easily penetrate the fabric of the rock via interlinked pores. Secondly, the individual grains of a quartzitic sandstone are not interlocked (as in a quartzite), but are held together with a cement of smaller crystals of quartz. Differential solubility with respect to grain size means that interstitial pore water may be saturated with respect to the larger sand grains, but still be undersaturated with respect to the small cementing crystals (which dissolve). There is a thermodynamic reason for this in that, mass for mass, small crystals have more energy tied up on their edges and faces. Differential solubitity has been used to explain why giant crystals of gypsum commonly protrude from walls and ceilings in the gypsum caves of western Ukraine (Klimchouk, 1996). A third reason is the presence of pyrite as a cementing material. Younger and Stunell (1995) suggest that oxidation of pyrite may be the main reason for arenisation in basal lag zones in the Fell Sandstone.

Against this, the many exposures of Fell Sandstone in natural rocky outcrops suggest that it is a material highly resistant to surface weathering. Further evidence is the widespread ocurrance of "cup and ring" marks, rock art dating from the Bronze Age. Those at Lordenshaw (NGR NZ

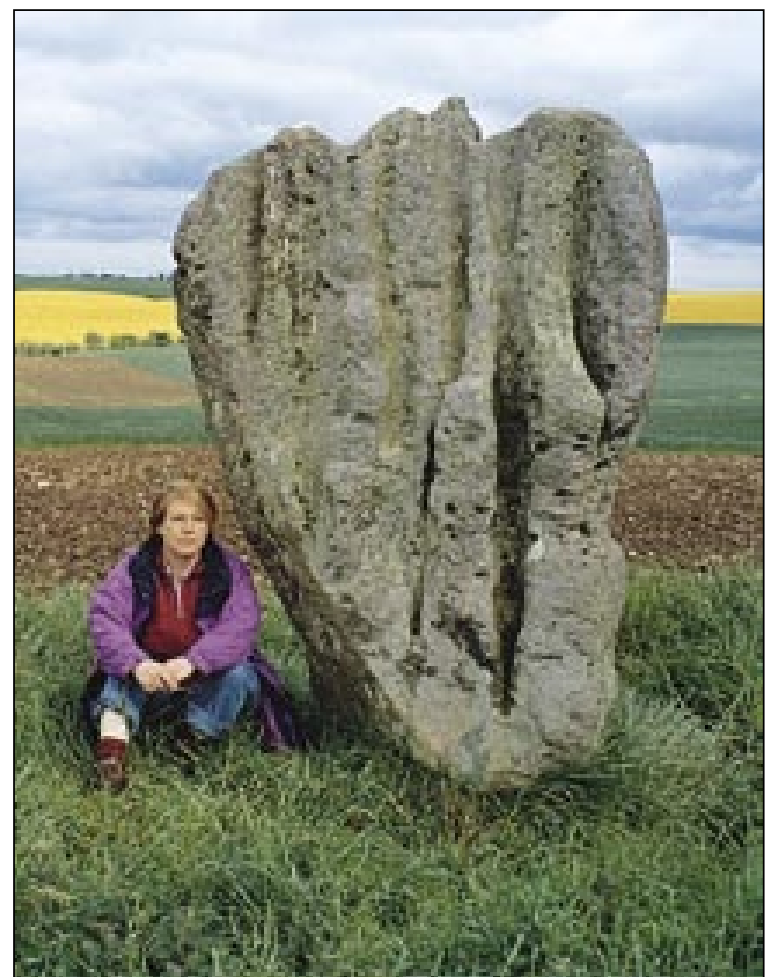

Figure 4: Decantation runnels on a standing stone, Duddo stone circle.
052992) have been exposed to wind and rain for about 4,000 years, yet are still perfectly preserved (Figure 5). On the same piece of rock, other cup marks are on a surface drainage route and have been cut by a decantation runnel. The standing stone circle at Duddo (Figure 4) has decantation runnels on every stone, which must have formed after the stones were erected. The runnels follow the bedding direction, which is now vertical, whereas in outcrop the Fell Sandstone is nearly horizontal in this vicinity. One stone has cup marks, still perfectly preseved, no more than $20 \mathrm{~cm}$ from a runnel (Figure 6).

The Fell Sandstone is a strong rock and generally quite resistant to surface weathering, though it does seem to be susceptible to arenisation along routes of concentrated drainage. Here the surface does not dry quickly after rain, but stays wet for extended periods of time. This may explain the coexistence of karren landforms with rock art, 


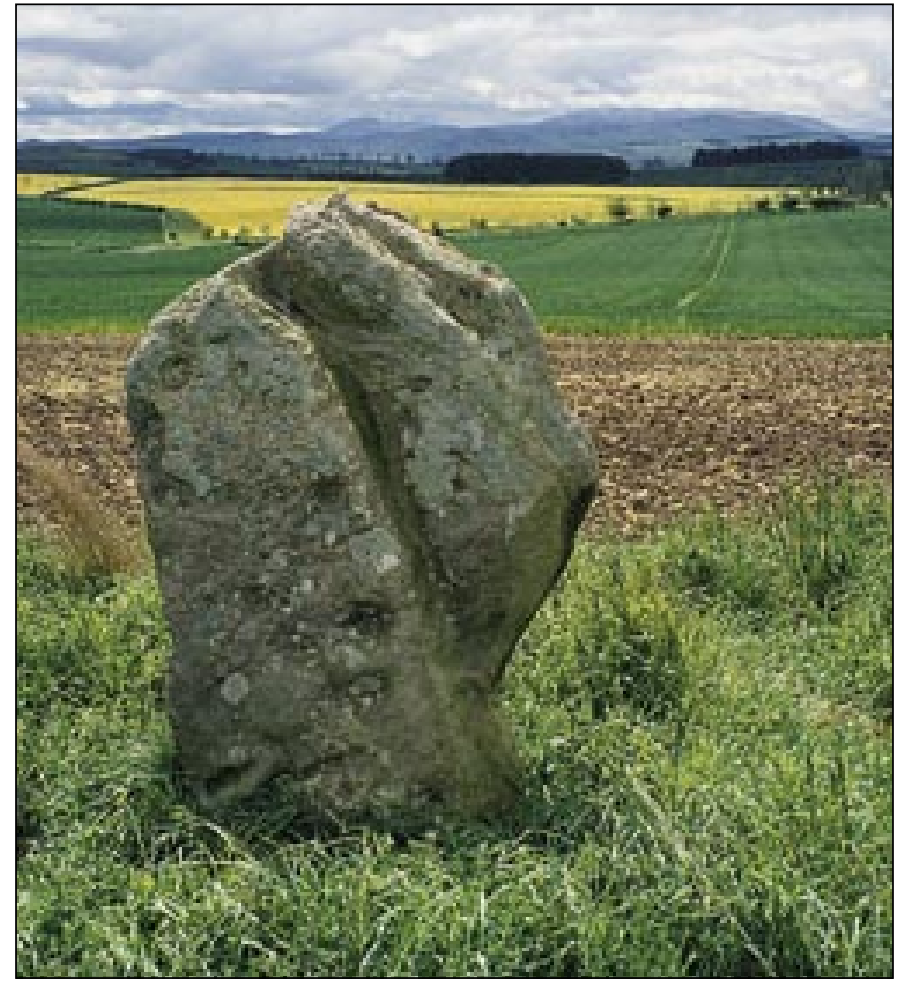

Figure 5: Bronze Age carvings on a rock outcrop, Lordenshaw.

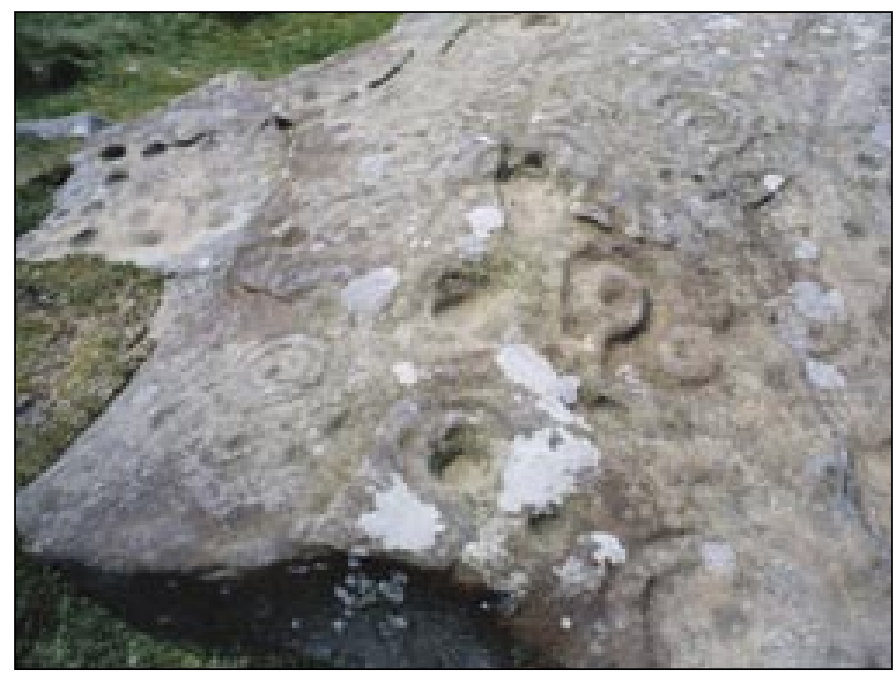

Figure 6: Decantation runnel and carved "cup marks" on a standing stone, Duddo stone circle. but it does not tell us how caves could form. Unlike in the case of quartzite karst, the rock is not generally arenised. This causes a problem for the inception of cave passages, since a long timescale should be needed to establish conduits large enough for turbulent flow and piping. Yet the caves are definitely Holocene, as the outcrops were glaciated during the Devensian. Herein lies a possible explanation. The caves are all very shallow, in strata that would have been affected by postglacial rebound. Tectonic inception horizons may have been created. Unlike those, which are neotectonic pathways, the preexisting joints and bedding planes of the Fell Sandstone would accommodate this movement.

The caves of Northumberland were probably formed by the favourable combination of tectonic inception, a robust rock and a lithology susceptible to arenisation on surfaces that stayed wet. This has allowed caves to form very quickly. Though it seems natural to compare sandstone karst with quartzite karst, the presence of porosity and cements should make arenisation (whether 
general or localised) proceed much more quickly in sandstones. Zupan Hajna (2005) is wrong to declare that Lapao Cave, a large sandstone cave in Brazil, "must be old" simply because of the slow rate of dissolution of quartz, though she may be correct for other reasons.

\section{IS THE FELL SANDSTONE A KARST LANDSCAPE?}

A major problem with the term "karst" is that different textbooks give significantly different definitions. According to Sweeting (1972), "all karst regions are areas of massive limestones". However, limestone is simply the end member of a sequence of rock types that goes through arenaceous limestone and calcareous arenite to sandstone. Karst features and caves are found in all members of this sequence. A lithological definition of karst, based on the percentage carbonate content of the host rock, must necessarily be arbitrary and would be difficult to assess during fieldwork. A cave (or even a single cave passage) developed in two beds with slightly different carbonate contents could be both karst and non-karst at the same time, a problem that would recur whatever the numerical value placed on this boundary.

Other authors suggest a process-based definition. White (1988) writes: "karst landscapes and their underlying caves are created by the chemical solution of the bedrock." This is the traditional view of karst as both landform and process and is the basis of most teaching in schools and universities. However, it has long been known that other processes operate in karst terrains. One answer has been: "the aspect of karst that distinguishes it from any other landscape is the dominance of solution as a geomorphic agent" (White, 1988). This is an assumption, not a fact, as detailed quantitative studies have yet to be made of major processes other than solution.

Mechanical abrasion is known to contribute to karst erosion in limestones (Newson, 1971), whether the agent is sediments carried in suspension in the cave stream or larger particles of the bed load. Some allogenic river caves may enlarge mainly by this method, particularly during flood episodes when the energy available to transport sediment greatly increases.

Another process, involving both solutional and mechanical elements, is incomplete dissolution and piping. Solution along grain boundaries weakens the fabric of the rock and allows individual grains to fall out or be washed away. This arenisation process was once thought to be restricted to silicate rocks, because the very slow rate of dissolution of quartz allows water to penetrate deep into the fabric of the rock before saturation is reached. It is now known to be widespread in limestone and dolomite terrains (Zupan Hajna, 2003) and has also been observed in very soluble gypsum (Andrejchouk to Zupan Hajna, pers. comm.).

Maturity is another important consideration in the balance between solutional and mechanical processes. Solution does appear to be the crucial process in the early stages of development of karst, "dissolution serving as the trigger mechanism for other processes" (Ford and Williams, 1989). This is particularly well illustrated by the case of "phantom" caves in calcareous sandstone (Hauselmann and Tognini, in press), where solution has created secondary porosity pathways without washing out the sand grains. The phantoms are seen in the walls of cave passages where piping has already occurred. There is no logic in describing the inaccessible phantom as karst (solution) and the accessible cave passage as non-karst (piping). The same argument could be used to include piping in poorly consolidated sediments into karst, since solution of the feeble intergranular cement allows secondary porosity caves to develop. 
We have argued before (Self \& Mullan, 1996) that karst is formed by a combination of processes, the exact balance between them depending on a combination of lithology, maturity, hydraulic gradient and other environmental factors. For this reason, we suggested that "karst" as a term should refer to a distinctive set of physical features in the landscape without reference to lithology or process. Many karst academics disagree, and insist on retaining phrases such as "high rock solubility" and "chemical solution" within the definition. We hope to have shown here that there is a continuum in the formation of caves by underground water between soluble and poorly soluble lithologies, between dissolution and mechanical erosion processes, and between consolidated and poorly consolidated materials. Solution has a crucial role only in the early stages of karst development.

Academic institutions should recognise the need for more research into the other processes that operate in karst terrains. Mechanical erosion is more clearly defined and easier to study in sandstones than in more soluble rocks. If such studies were fully accepted as karst research, this could provide insights into the karst erosion process as a whole in more soluble rocks such as limestone.

\section{ACKNOWLEDGEMENTS}

Discussions during the $13^{\text {th }}$ International Karstological School held in Postojna in 2005 provided the impetus for this paper. The topic of the School was "karst in various rocks" and reference is made in this paper to presentations that were made there.

\section{REFERENCES}

Ford, D.C. \& Williams, P.W., 1989: Karst Geomorphology and Hydrology. London. Unwin Hyman. $601 \mathrm{pp}$.

Hauselmann, P. \& Tognini, P., 2005: Kaltbach Cave (Siebenhengste, Switzerland): phantom of the sandstone? Acta carsologica, 34 (in press)

Klimchouk, A,: 1996. Dissolution and conversions of gypsum into anhydrite. International Journal of Speleology, 25 (3-4), p. 21-36.

Martini, J., 2004: Silicate karst. p. 649-653 in Gunn, J. (ed.) Encyclopedia of Caves and Karst Science. New York and London, Fitzroy Dearborn.

Newson, M.D., 1971: The role of abrasion in cavern development. Transactions of the Cave Research Group of Great Britain, 13 (2), p. 101-107.

Robson, D.A., 1956: Sedimentary study of the Fell Sandstones of the Coquet Valley, Northumberland. Quarterly Journal of the Geological Society of London, 112, p. 241-262.

Self, C.A. \& Mullan, G.J., 1996: Redefining the boundary between karst and pseudokarst. Cave and Karst Science, 23 (2), p. 63-70.

Sweeting, M.M., 1972: Karst Landforms. London. The MacMillan Press. 362 pp.

Turner, B.R., Younger, P.L. \& Fordham, C.E., 1993. Fell Sandstone Group lithostratigraphy southwest of Berwick-upon-Tweed: Implications for the regional development of the Fell Sandstone. Proceedings of the Yorkshire Geological Society, 49, p. 269-281

White, W.B., 1988: Geomorphology and Hydrology of Karst Terrains. New York. Oxford University Press. $464 \mathrm{pp}$

Younger, P.L. and Stunell, J.M., 1995: Karst and Pseudokarst: An Artificial Distinction? p. 121-142 in Brown, A.G. (ed.), Geomorphology and Groundwater. London. John Wiley \& Sons Ltd. 
Zupan Hajna, N., 2003: Incomplete solution: weathering of cave walls and the production, transport and deposition of carbonate fines. Postojna - Ljubljana, Slovenia, Carsologica, ZRC Publishing, Slovenian Academy of Sciences and Arts. 167pp.

Zupan Hajna, N., 2005: "Karst features" in quartz sandstones - Lapao Cave, Bahia, Brasil. 13 ${ }^{\text {th }}$ International Karstological School, Postojna. (Poster) 